\title{
THE ALLEVIATIVE EFFECT OF THYMOQUINONE ON CEREBELLAR INJURY INDUCED BY FOOD AZO DYE IN RATS
}

\author{
By \\ Eman S. Mahmoud, Azza H. Abd Elwahab* and Asmaa F. Yousuf* \\ Departments of Histology and Physiology*, Faculty of Medicine for Girls (Cairo), Al- \\ Azhar University
}

\begin{abstract}
Background: Tartrazine (Tz) is one of the most commonly used food additive and synthetic color that is added to food for attracting the consumers' vision. However, it might cause many toxic effects on the long run.

Objectives: This study aimed to evaluate the potential ameliorating effect of thymoquinone (TQ) against possible neurotoxic effect of $\mathrm{Tz}$.

Materials and Methods: Forty adult male rats were allocated into four groups: Group (1) received distilled water, Group (2) was given $10 \mathrm{mg} \mathrm{TQ} / \mathrm{kg}$ b.wt., Group (3) was given Tz (7.5 mg/kg b.wt.) and Group (4) was given TQ concurrently with Tz. All treatments were given orally daily for 30 days. Brain neurotransmitters; norepinephrin (NE), dopamine (DA), serotonin (5HT) and gamma amino butyric acid (GABA) beside glutathione (GSH), catalase (CAT), malondialdehyde (MDA), tumor necrosis factor- $\alpha$ (TNF$\alpha$ ), Bcl-2 associated X (Bax) protein, and B-cell lymphoma-2 (Bcl-2) were evaluated in cerebellar homogenate. Also, histological and immunohistochemical examinations for cerebellar tissue were studied.

Results: Tartrazine significantly decreased NE, DA, 5HT and GABA; as well as GSH and CAT with increased MDA, while TNF- $\alpha$ and Bax showed significant increase versus decreased Bcl-2. Nevertheless, TQ significantly increased NE, DA, 5HT and GABA as well as GSH and CAT beside Bcl-2, while decreasing MDA, TNF- $\alpha$ and Bax. Histologically, the swelling and vacuolar degeneration of the cerebellar cortex with decrease numbers of Purkinje cells and the increased apoptotic cell number that were noticed in Tz treated group improved after TQ supplementation.
\end{abstract}

Conclusion: Thymoquinone could be a good candidate for modulation of $\mathrm{Tz}$ - induced neurotoxicity through its antioxidant, neurotransmitter modifying, anti-neuroinflammatory and anti-apoptotic effects.

Key words: Thymoquinone, Tartrazine, azo dye, cerebellum, neurotoxicity.

\section{INTRODUCTION}

Tartrazine is a commonly used food color additive that is widely used all over the world. However, it might cause many toxic effects especially on the nervous system through its metabolites, e.g. monosodium glutamate and nitrous compounds, that are found to be carcinogens (Amin and Al-Shehri, 2018).

Among foods containing $\mathrm{Tz}$ are soft drinks and sport drinks, flavored chips, sauces, ice creams, jams, jellies and chewing gums. Also, it is found in many non-food consumables such as soaps, cosmetics, shampoos, vitamins and certain 
prescription medications. Moreover, it is used in many developing countries as a low cost alternative for saffron in cooking (Amin et al., 2010).

Tartrazine is a water soluble artificial food color derived from coal tar or petroleum by-products. Inside the body, $\mathrm{Tz}$ is reduced to an aromatic amine which is greatly sensitized, since it is a nitrous derivative (azo class). The chief metabolites recognized so far is sulfanilic acid and aminopyrazolone via the gut microflora and possibly by mammalian azo reductase in the hepatic or intestinal wall after consumption (Chequer et al., 2011-a). When these azo dyes are reduced totally into aromatic amines, they are oxidized to N-hydroxy derivatives by the enzymatic system of P450. This mechanism of biotransformation takes place in many species including humans, which is responsible for various disorders including anemia, pathological lesions in the brain, liver, kidney and spleen, beside allergic reactions, tumor and cancer pathological lesions in various organs beside variety of immunologic responses, genotoxicity, neurotoxicity and cancer (Mohamed et al., 2015, Sekeroglu, et al. 2017and Amin \& Al-Shehri, 2018).

The brain is highly vulnerable to the damage caused by free radicals because of its rapid oxidative metabolic activity, high polyunsaturated fatty acids content, relatively low antioxidant capacity, and inadequate neuronal cell repair activity. Therefore, brain tissues are predominantly susceptible to oxidative damage by food additives specially cerebellum that was found to be exhibit changes in its cortex in the form of swelling, vacuolar degeneration in all layers mainly in white matter, which induced by oxidative stress of tartrazine metabolism.(Ghonimi and Elbaz, 2015). Increasing evidence demonstrated that dietary supplementation with nutritional antioxidants could reduce oxidative stress, limit brain damage and improve behavioral functions (Guo et al., 2011).

Thymoquinone is the main constituent of the volatile oil derived from $\mathrm{N}$. sativa seeds. It has different pharmacological properties such as anticonvulsant, antitussive, and anti-tumor as well as antiinflammatory and antioxidant activities (Elmaci and Altinoz, 2016). TQ crosses the blood brain barrier and exerts neuromodulatory activities. It has a neuroprotective effect against neurotoxicty induced by heavy metals and radiation (Kassab and El-Hennam, 2017).

The present study aimed to evaluate the potential protective effect of TQ on rat model of $\mathrm{Tz}$ neurotoxicity (specifically the cerebellum), and to investigate the possible protective mechanism by which TQ could ameliorate such toxicity.

\section{MATERIALS AND METHODS}

\section{Drugs and Chemicals:}

Tatrazine (CAS 1934-21-0, Purity $86.7 \%$ ), orange yellow fine power was purchased from Sigma Aldrich (MO, USA). TQ was purchased from SigmaAldrich Corp (MO, USA). TQ is yellowish crystalline powder that is soluble in water.

\section{Experimental design:}

Adult male albino rats of local strain weighing from 120 to $150 \mathrm{~g}$ were used in this study. They were housed in clean properly ventilated cages $(150 \times 60 \times 50 \mathrm{~cm}-$ 
5 rats/ cage) under the same environmental conditions with free access to food and water throughout the experiment with normal light/dark cycle. The animals were randomly divided into four equal groups as follows:

- Group I (control group): Animals were orally given distilled water (1 $\mathrm{ml} / \mathrm{kg}$ b.wt. daily) for 30 days.

- Group II (TQ group): Animals were orally given TQ in a dosage of 10 $\mathrm{mg} / \mathrm{kg}$ b.wt. Daily for 30 days (Safhi, 2016) via intragastric route, freshly prepared by dissolving in distilled water.

- Group III (Tz group): Animals were orally given $\mathrm{Tz}(7.5 \mathrm{mg} / \mathrm{kg}$ b.wt.) daily for 30 days (dissolved in $1 \mathrm{ml}$ of distilled water) (Bhatt et al., 2018).

-Group IV (TQ +Tz group): Animals were orally given TQ plus Tz daily for 30 days, same dosage in each as in GII \& GIII.

At the end of the experiment, brains were removed and dissected. Cerebellar hemispheres were removed; one of cerebellar hemisphere was prepared, homogenized using an electrical homogenizer by mixing $0.5 \mathrm{~g}$ of tissue with $5 \mathrm{ml}$ phosphate buffer saline at $4{ }^{\circ} \mathrm{C}$. The homogenates were centrifuged at $3000 \mathrm{rpm}$ for $15 \mathrm{~min}$. The collected supernatant was conserved at $-20 \circ \mathrm{C}$ until further used for performance of the biochemical measurements. The other was fixed for histopathological studies (Bancroft and Gamble, 2001).

\section{Biochemical measurements:}

1. Cerebellar oxidative stress biomarkers assay: GSH was evaluated by the methods of (Ellman, 1959), CAT activity was estimated using commercial kits (Biodiagnostic, Egypt), and lipid peroxidation byproduct; MDA in brain homogenate were estimated according to the method of (Ohkawa et al., 1979).

2. Cerebellar neurotransmitters (NT) assay: The tested NE, DA, 5HT and GABA were measured by high performance liquid chromatography (HPLC) according to the method of (Pagel et al., 2000).

3. Inflammatory and apoptotic markers of Cerebellar homogenate: TNF- $\alpha$ was measured by quantitative ELISA kits purchased from R\&D Systems Inc, USA. Bcl-2 protein and Bax protein levels were measured in tissue lysates by ELISA kits, Uscn Life Science Inc.

\section{Histological methods:}

\section{1- Light microscopic examination:}

At the end of the experiment, the animals were anesthetized with isoflurine inhalation, then intracardiac perfusion was done by $2 \%$ glutaraldehyde for partial fixation of brain. The brain was dissected, and the cerebellum was fixed in $10 \%$ neutral buffered formalin for $48 \mathrm{~h}$ for light microscopy analysis, dehydrated in ascending grads of alcohol, cleared in xylene, embedded in paraffin and then sections were cut at 5-7 ?m with microtome, mounted on glass slides and stained with hematoxylin and eosin for routine histological examination (Bancroft and Gamble, 2001).

Cresyl violet stain used to distinguish between the viable normal cells and degenerated neurons which had lightly stained nuclei with shrunken cell bodies (Pamidi et al., 2014). 


\section{Immunohistochemical study:}

Sections were taken on positive slides and immunostained using avidin-biotin technique (Zarnescu et al., 2008). Slides were deparaffinized, rehydrated, embedded in $0.01 \% \mathrm{H} 2 \mathrm{O} 2$ was carried out by transmitting sections into $0.01 \mathrm{M}$ citrate buffer ( $\mathrm{pH}$ 6) for 10 minutes in ethanol for 10 minutes. Slides were boiled in a microwave at temperature grade VIII for 4 minutes followed by 2 minutes at grade II. Incubation in $1 / 100$ normal rabbit serum for 20 minutes was done in order to omit nonspecific background. The slides were incubated for two hours with the diluted primary antibody at dilution $1 / 500 \& 1 / 400$ biotinylated polyclonal rabbit antibody for BAX (Thermo Fisher Scientific $^{\mathrm{TM}}$ Catalog \#: MA5-14003, dilution 1:50). Avidin-Biotin Complex $(\mathrm{ABC})$ reagent was prepared and left for 30 minutes and sections were incubated with the $(\mathrm{ABC})$ reagent for 60 minutes then incubated in peroxidase substrate solution for 6-10 minutes. Finally, hematoxylin was used as a counter stain, dehydrated in absolute alcohol, cleared and mounted. For the negative control slide, the specific 1ry antibody was replaced by phosphate buffer saline.

\section{3- Histomorphometrical analysis:}

Lica Qwin 500 LTD image analysis microscope, Faculty of Dentistry (girls), Al- Azhar University, was used in this study for estimation of the numbers of apoptotic cells in BAX stained sections at 200X magnification, and apoptotic index was calculated by counting a total number of at least 1000 cells per slide subdivided in 10 fields chosen randomly from all layers of cerebrellum.

$\mathrm{AI} \%=[$ number of positive cells/total number of calculated cells] $\times 100$ is the percentage of positive cells in 1000 cells (Xu et al., 2007). Optical density of Bax reaction in cerebrellar cortex in all studied groups was measured in five randomly selected non overlapping fields using 200X magnification.

\section{Statistical analysis:}

The results were statistically analyzed using statistic package for social science version 12 (SPSS, 12) for windows and was expressed as Mean \pm Standard Error of Mean (SEM). Variables of chemical data statistically analyzed using one-way analysis of variance (ANOVA) for a completely randomized design followed by Tukey multiple comparison tests. Variables of histological studies were tested for normal distribution and compared using the independent Student's t-test. The level of significance was taken at $\mathrm{P}$ value of $<0.05$.

\section{RESULTS}

Tartrazine treated rats exhibited significant decrease in the measured brain neurotransmitters; NE, DA, 5HT and GABA, when compared to normal rats. Administration of TQ concomitantly with
$\mathrm{Tz}$ resulted in improvement in the previously measured brain transmitters by significantly increasing them if compared to Tz-treated rats $(\mathrm{P}<0.05)$ (Figure $1 \mathrm{~A}$ $\& B)$. 

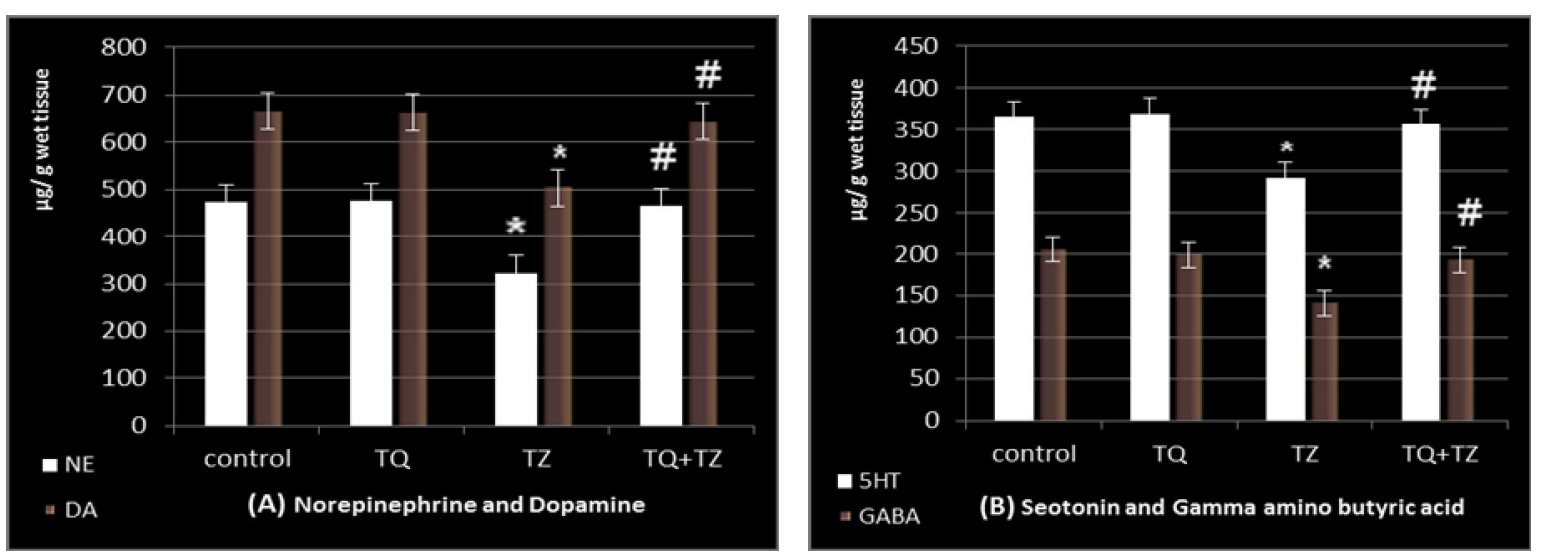

Figure (1): Effect of thymoquinone treatment on tartrazine induced changes on: (A) norepinephrine and dopamine and (B) serotonin and Gamma amino butyric. Data represent the means \pm SEM, (*, \#) significant values compared with control, tartrazine; respectively, $\mathrm{P}<0.05$ ), using one-way ANOVA followed by Tukey multiple comparison test.

Rats treated with $\mathrm{Tz}$ revealed significant disturbance in the measured oxidative stress markers; decreased GSH and CAT with the increased MDA when compared to normal rats. On the other hand, when TQ was administered concomitantly with $\mathrm{Tz}$, it ameliorated the apparent oxidative stress by significantly increasing GSH and CAT, beside significantly decreasing MDA when compared to TQ group (Table 1).

Table (1): Effect of thymoquinone treatment on cerebellar GSH (mmol/g tissue), CAT (u/mg tissue) and malondialdehyde (nmol/ g tissue) of tartrazine administered rats

\begin{tabular}{|c|c|c|c|c|c|}
\hline Groups & $\begin{array}{l}\text { Control } \\
\text { ( I ) }\end{array}$ & $\begin{array}{c}\text { Thymoquinone } \\
\text { Group } \\
\text { ( II ) }\end{array}$ & $\begin{array}{l}\text { Tartrazine } \\
\text { Group } \\
\text { ( III ) }\end{array}$ & $\begin{array}{c}\text { Tartrazine } \\
\text { Group treated } \\
\text { with } \\
\text { thymoquinone } \\
\text { (IV ) }\end{array}$ & ANOVA \\
\hline Parameters & $\begin{array}{l}\text { Mean } \pm \\
\text { S.E.M. }\end{array}$ & Mean \pm S.E.M. & $\begin{array}{l}\text { Mean } \pm \\
\text { S.E.M. }\end{array}$ & Mean \pm S.E.M. & P- value \\
\hline $\begin{array}{c}\text { GSH } \\
\text { (mmol/g } \\
\text { tissue) }\end{array}$ & $1.54 \pm 0.07$ & $1.6 \pm 0.05$ & $\begin{array}{c}0.93^{\mathrm{a}} \pm \\
0.02\end{array}$ & $1.47^{c} \pm 0.04$ & 0.003 \\
\hline $\begin{array}{c}\text { CAT (u/mg } \\
\text { tissue) }\end{array}$ & $36.43 \pm 1.3$ & $36.12 \pm 1.2$ & $21.6^{\mathrm{a}} \pm 1.5$ & $34.05^{b, c} \pm 1.3$ & 0.002 \\
\hline $\begin{array}{l}\text { MDA (nmol/ } \\
\text { g tissue) }\end{array}$ & $4.85 \pm 0.12$ & $4.75 \pm 0.12$ & $7.61^{a} \pm 0.28$ & $5.08^{c} \pm 0.22$ & 0.001 \\
\hline
\end{tabular}

$\mathrm{a}, \mathrm{b}$, c: significant values compared to control, thymoquinone group, tartrazine group respectively.

Significant values when $\mathrm{P}<0.05$, using one-way ANOVA followed by Tukey multiple comparison test.

Tartrazine treatment induced significant increase in inflammatory marker TNF- $\alpha$ and the proapoptotic factor
Bax versus the significant decrease in the antiapoptotic marker Bcl-2 when compared to control group. Alternatively, 
TQ administered rats with $\mathrm{Tz}$ showed improvement in the previous disturbances in the form of significant decrease in
TNF- $\alpha$ and Bax and increase in Bcl-2 if compared to $\mathrm{Tz}$ group.

Table (2): Effect of thymoquinone treatment on cerebellar TNF- $\alpha$ (pg/mg tissue), Bax (ng/mg tissue) and Bcl-2 (ng/mg tissue) of tartrazine administered rats

\begin{tabular}{|c|c|c|c|c|c|}
\hline Groups & $\begin{array}{l}\text { Control } \\
\text { ( I ) }\end{array}$ & $\begin{array}{c}\text { Thymoquinone } \\
\text { Group } \\
\text { ( II ) }\end{array}$ & $\begin{array}{c}\text { Tartrazine } \\
\text { Group } \\
\text { ( III ) }\end{array}$ & $\begin{array}{c}\text { Tartrazine } \\
\text { Group treated } \\
\text { with } \\
\text { thymoquinone } \\
\text { (IV) }\end{array}$ & ANOVA \\
\hline Parame & $\begin{array}{l}\text { Mean } \pm \\
\text { S.E.M. }\end{array}$ & Mean \pm S.E.M. & $\begin{array}{l}\text { Mean } \pm \\
\text { S.E.M. }\end{array}$ & Mean \pm S.E.M. & P-value \\
\hline $\begin{array}{c}\text { TNF- } \alpha \text { (pg /g } \\
\text { tissue) }\end{array}$ & $\begin{array}{c}15.35 \pm \\
0.72\end{array}$ & $15.07 \pm 0.78$ & $41.19^{a} \pm 2.03$ & $16.12^{c} \pm 0.8$ & 0.009 \\
\hline $\begin{array}{c}\text { Bax (ng /mg } \\
\text { tissue) }\end{array}$ & $\begin{array}{c}4.74 \pm \\
0.16\end{array}$ & $4.43 \pm 0.15$ & $11.27^{\mathrm{a}} \pm 0.2$ & $5.01^{\mathrm{b}, \mathrm{c}} \pm 0.17$ & 0.002 \\
\hline $\begin{array}{c}\text { Bcl-2 (ng / g } \\
\text { tissue) }\end{array}$ & $\begin{array}{c}35.5 \pm \\
1.21\end{array}$ & $36.13 \pm 1.2$ & $19.07^{\mathrm{a}} \pm 1.4$ & $31.68^{\mathrm{b}, \mathrm{c}} \pm 1.7$ & 0.003 \\
\hline
\end{tabular}

a, b, c: significant values compared to control, thymoquinone group, tartrazine group respectively. Significant values when $\mathrm{P}<0.05$, using one-way ANOVA followed by Tukey multiple comparison test.

Histologically, the cerebellar cortex is formed of folds called folia which enclose central cores of white matter outer grey matter and inner white matter, the grey matter formed of three layers, the molecular layer lies directly under pia mater and consists of neutrophil with fewer stellate cells which are sparse, dendrites of Purkinje cells, basket cells, and unmyelinated axons from the granular layer. The second layer is Purkinje cell layer contains the large, flask-shaped Purkinje cells, the dendrites of Purkinje cells have hundreds of small branches, each covered with dendritic spines project into the molecular layer and their myelinated axons project into to join tracts in the medulla white matter and basket cells surround cell body of purkinje. The third layer is the granular layer (the deepest layer) consists of small granule cells which are packed together densely and glomeruli (cerebellar islands). Glomeruli are regions of the cerebellar cortex where synapses are taking place between axons entering the cerebellum and the granule cells (Figure 2), same results seen in TQ treated sections (Figure $3)$.

Tertazine administration exerted histopathological effects on the cerebellar cortex in the form of swelling, vacuolar degeneration (spongiosis) in all layers mainly in white matter with little effects on grey matter. Purkinje cells shrunken and lost in focal areas, and have deeply stained cytoplasm, irregular outlines, and small pyknotic nuclei (karyopyknosis), as well as destruction of some cells with lose of axons of some of them (Figure 4). These effects significantly decreased in group IV after usage of TQ with Tz (Figure 5). 
In the cresyl violet stained section normal purkinje cells were present in control and TQ-treated groups. The numbers of degenerated purkinje cells significantly increased in Tz-treated group if compared to control group (Figure 6).
The number of apoptotic cells was also seen in all layers and significantly increased if compared to control group when sections stained with BAX (Figure 7).

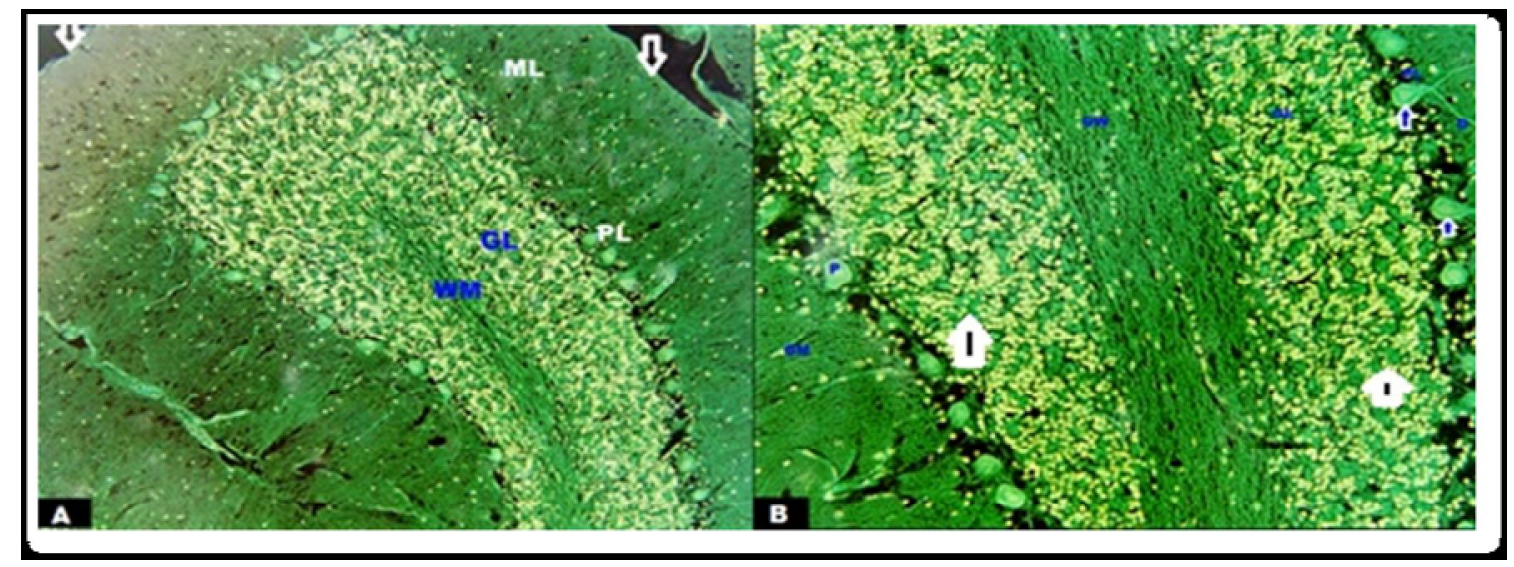

Figure (2): Photomicrographs of cerebellar cortex of control group (G I) showed: (A) pia matter covering ( $\checkmark$ ), 3 layers of grey matter; outer molecular (ML), purkinje cell layer (PL), and granular layer (GL) with its closely packed nuclei and white matter (WM). (B) The layers were seen with appearance of glomeruli ( $\widehat{u}$ ), pyramidal cell $(\mathrm{P})$ with its flask shaped and its vesicular nucleus ( $\boldsymbol{D}$ ), its dendrites (D) (H\&E 100\&200X).

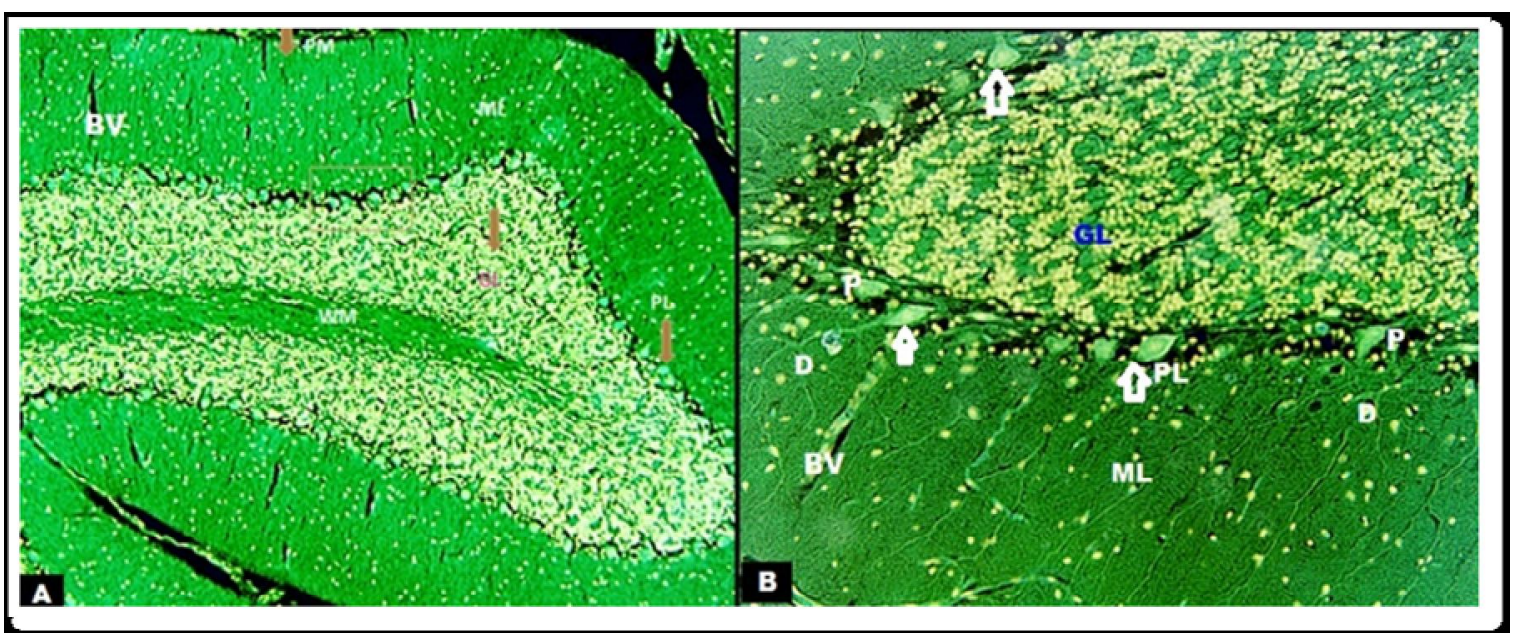

Figure (3): Photomicrographs of cerebellar cortex of thymoquinone treated group (GII) showed: (A) pia matter (PM) covering ( ) and white matter (WM), 3 layers of grey matters outer molecular (ML), purkinje cell layer (PL), and granular layer (GL). (B) Showed pyramidal cell (P) with its flask shaped and its vesicular nucleus ( $\mathbf{D}$ ), its dendrites (D), blood vessels (BV) (H\&E 100\&200X). 


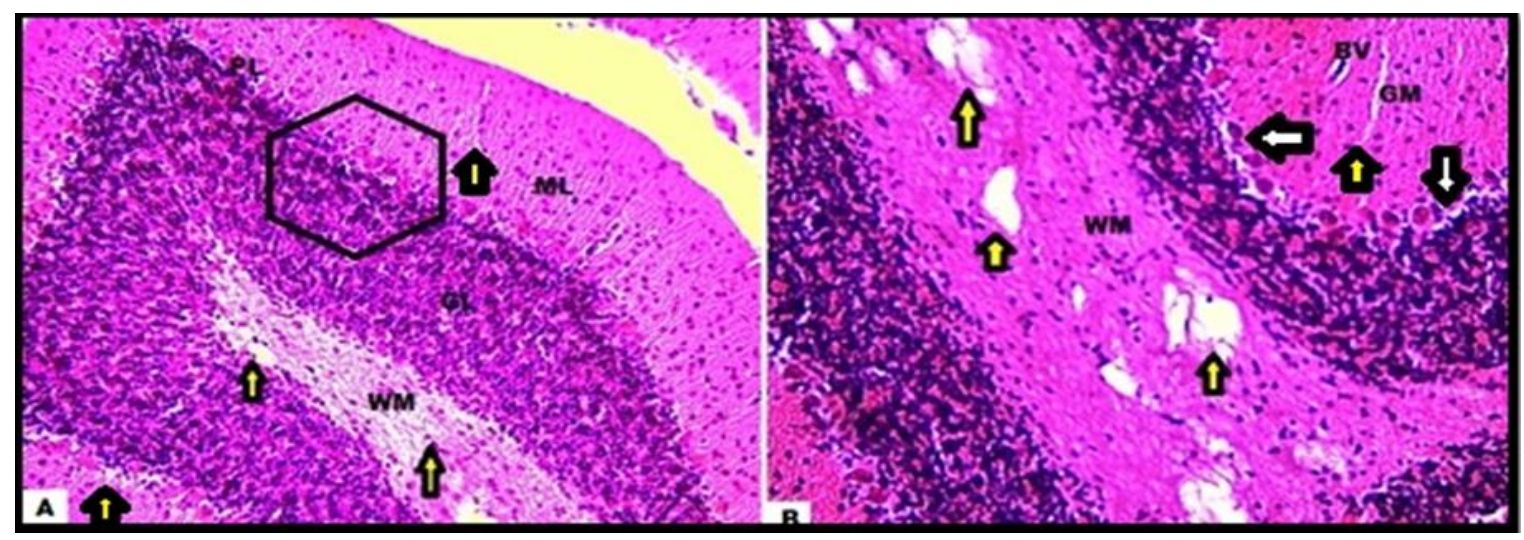

Figure (4): Photomicrographs of cerebellar cortex of (GIII) tetrazine treated group showed molecular layer (ML), purkinje cell layer (PL) and granular layer (GL) with vacuolar dilatation in the all layers mainly white matter (WM ) ( $)$ ), with destruction and apoptosis of purkinje cells ( $\mathbf{D}$ ). (B) Showed grey matter (GM), white matter $(\mathrm{WM})$, vacuolation ( $\boldsymbol{\boldsymbol { T }})$, purkinji cells with pyknotic nuclei $(\longleftarrow)$, dilated blood vessels (BV) (H\&E 100\&200X).

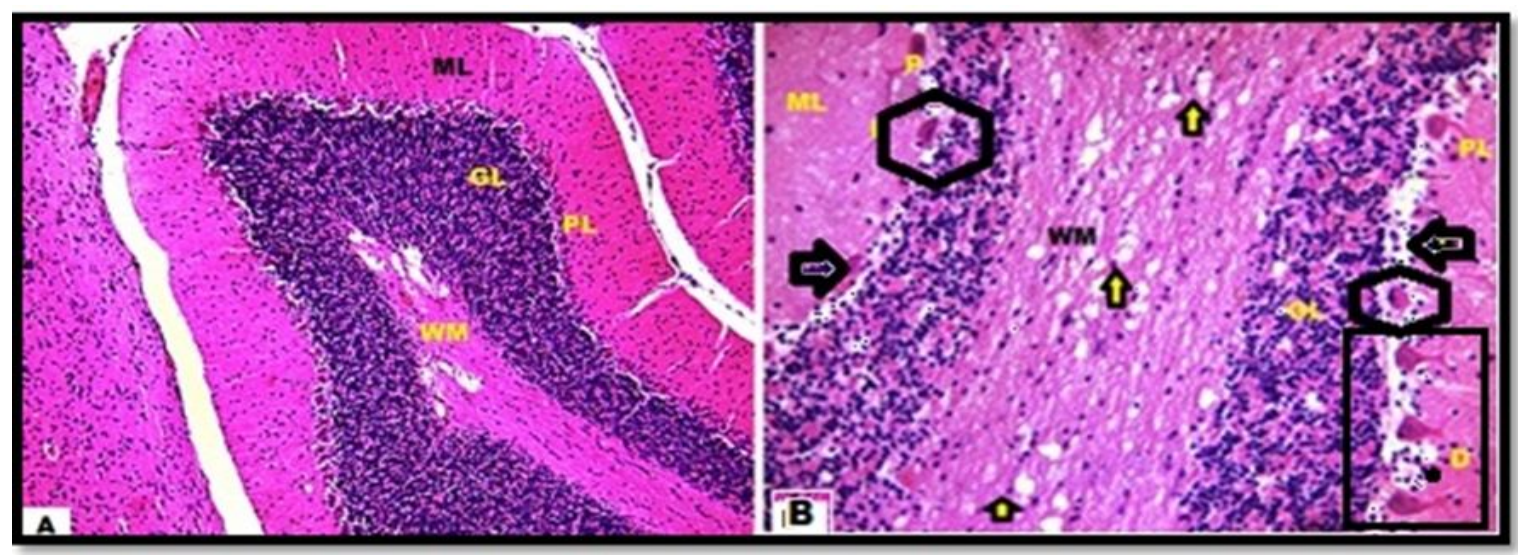

Figure (5): Photomicrographs of cerebellar cortex of tetrazine + thymoquinone treated group (GIV) Showed: (A) Molecular layer (ML), purkinje cell layer (PL) and granular layer (GL), and less vacuolar dilatation in white matter (WM). (B) Showed destruction and apoptosis of purkinje cells (p) ( $\mathbf{D}$ ), with small pkynotic nucleus $(\boldsymbol{\square})$ and dendrites (D), and normal purkinje cells ( $\square(\mathbf{H \& E}$ 100\&200X). 


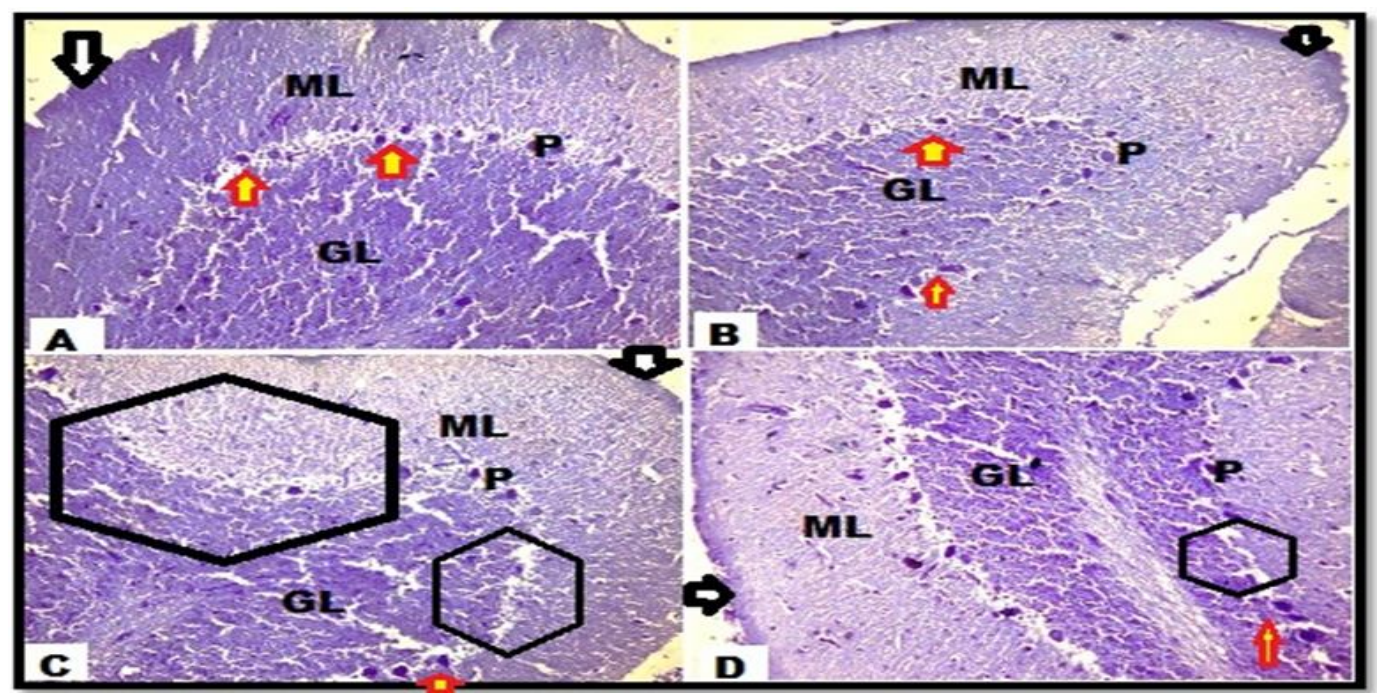

Figure (6): Photomicrographs of cerebellar cortex showed molecular layer (ML), granular layer (GL) and normal purkinje cells (P) ( $(-)$ more in A $(\boldsymbol{G I}) \&$ B $(\boldsymbol{G I I})$ slides. (C): $(\boldsymbol{G I I I})$ Showed loss of purkinje cells in certain areas ( $\mathbf{D}$ ) with destruction and degenerated purkinje cells (P). (D): (GIV) Showed normal purkinje cells (P) ( 1 ), destructed purkinje cells ( ) which decrease than $\mathrm{C}$ slid, pia matter ( (Creysl Vilot 200x).

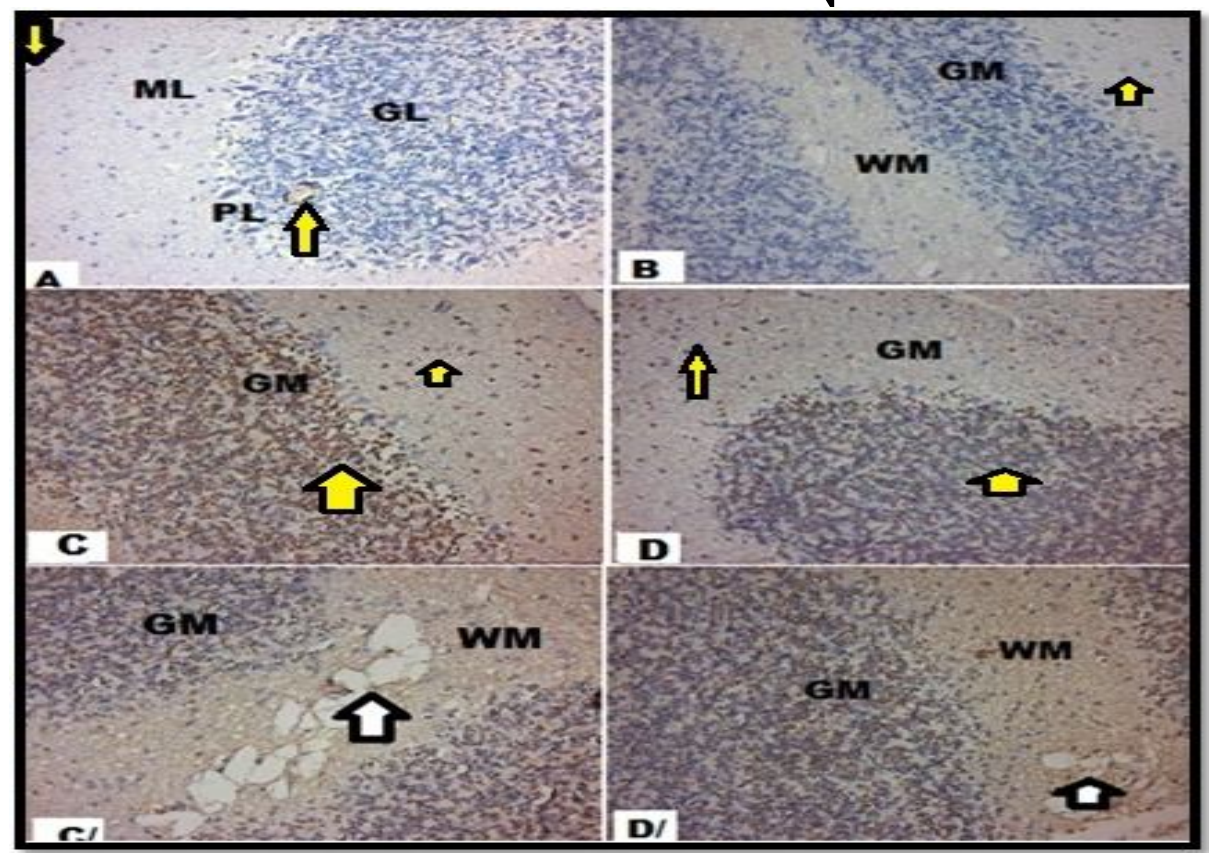

Figure (7): Photomicrographs of cerebellar cortex of showed Grey matter (GM), molecular layer (ML), purkinje cell layer (PL), and granular layer (GL), very few BAX reaction in A (GI) \& B (GII) slides ( $\mathbf{T}$ ). Increased reaction in $\mathbf{C}$ slide (GIII) and appear in all layers \& which slightly decrease in D slide (GIV). C/\&D/ slides shows the reactions and vacuolation ( $\mathbb{T}$ ) of white matter (WM) in GIII\&GIV respectively (BAX immuostain 200x).

By studying the mean optical density of BAX immune histochemical reaction, it was noticed that the highest mean was recorded among the Tz-treated group
(175.9 \pm 17.42 ) followed by the Tz- and TQ- treated group $(109.624 \pm 10.94)$. The least mean was recorded among the control group $(44.52 \pm 5.283)$ followed by 
the TQ-treated group (58.4 \pm 4.973$)$. These findings were of statistically significant values $(\mathrm{P} \leq 0.001)$ (Table 3 \&Figure 8$)$.

Also, apoptotic index (AI) showed significant increase in Tz-treated group
(21.26 \pm 5.72$)$ if compared to control group $(1.415 \pm 0.594)$ \& TQ-treated group (3.887 \pm 6.456$)$, with non-significant difference in $\mathrm{Tz}+$ TQ-treated group $(19.908 \pm 18.15)$ (Table $3 \&$ Figure 8).

Table (3): Effect of Tartrazine on optical density and apoptotic index means of BAX immunohistochemical reaction)

\begin{tabular}{|c|c|c|c|c|c|}
\hline Grou & $\begin{array}{l}\text { Control } \\
\text { ( I ) }\end{array}$ & $\begin{array}{c}\text { Thymoquinone } \\
\text { Group } \\
\text { ( II ) }\end{array}$ & $\begin{array}{c}\text { Tartrazine } \\
\text { Group } \\
\text { ( III ) }\end{array}$ & $\begin{array}{c}\text { Tartrazine } \\
\text { Group treated } \\
\text { with } \\
\text { thymoquinone } \\
\text { (IV ) }\end{array}$ & ANOVA \\
\hline Parameters & $\begin{array}{l}\text { Mean } \pm \\
\text { S.E.M. }\end{array}$ & Mean \pm S.E.M. & $\begin{array}{l}\text { Mean } \pm \\
\text { S.E.M. }\end{array}$ & Mean \pm S.E.M. & P-value \\
\hline $\begin{array}{c}\text { BAX (optic } \\
\text { density) }\end{array}$ & $44.52 \pm 5.283$ & $58.4 \pm 4.973$ & $\begin{array}{c}175.9 \\
\mathbf{2}+17.42 \\
\end{array}$ & $\begin{array}{l}109.624 \\
b_{ \pm} \pm 10.94 \\
\end{array}$ & 0.008 \\
\hline $\begin{array}{l}\text { APOPPTOTIC } \\
\text { INDEX (AI\%) }\end{array}$ & $1.415 \pm 0.594$ & $3.887 \pm 6.456$ & $\begin{array}{l}21.26 \\
? \pm 5.72 \\
\end{array}$ & $19.908^{b} \pm 18.15$ & 0.002 \\
\hline
\end{tabular}

Data were expressed as Mean \pm SEM. and analyzed using one-way ANOVA followed by Bonferroni post hoc multiple comparison test. Difference between groups was considered statistically significant when $\mathrm{P} \leq 0.05$.

(a) Significant values versus group control, (b) Significant values versus Tartrazine group.

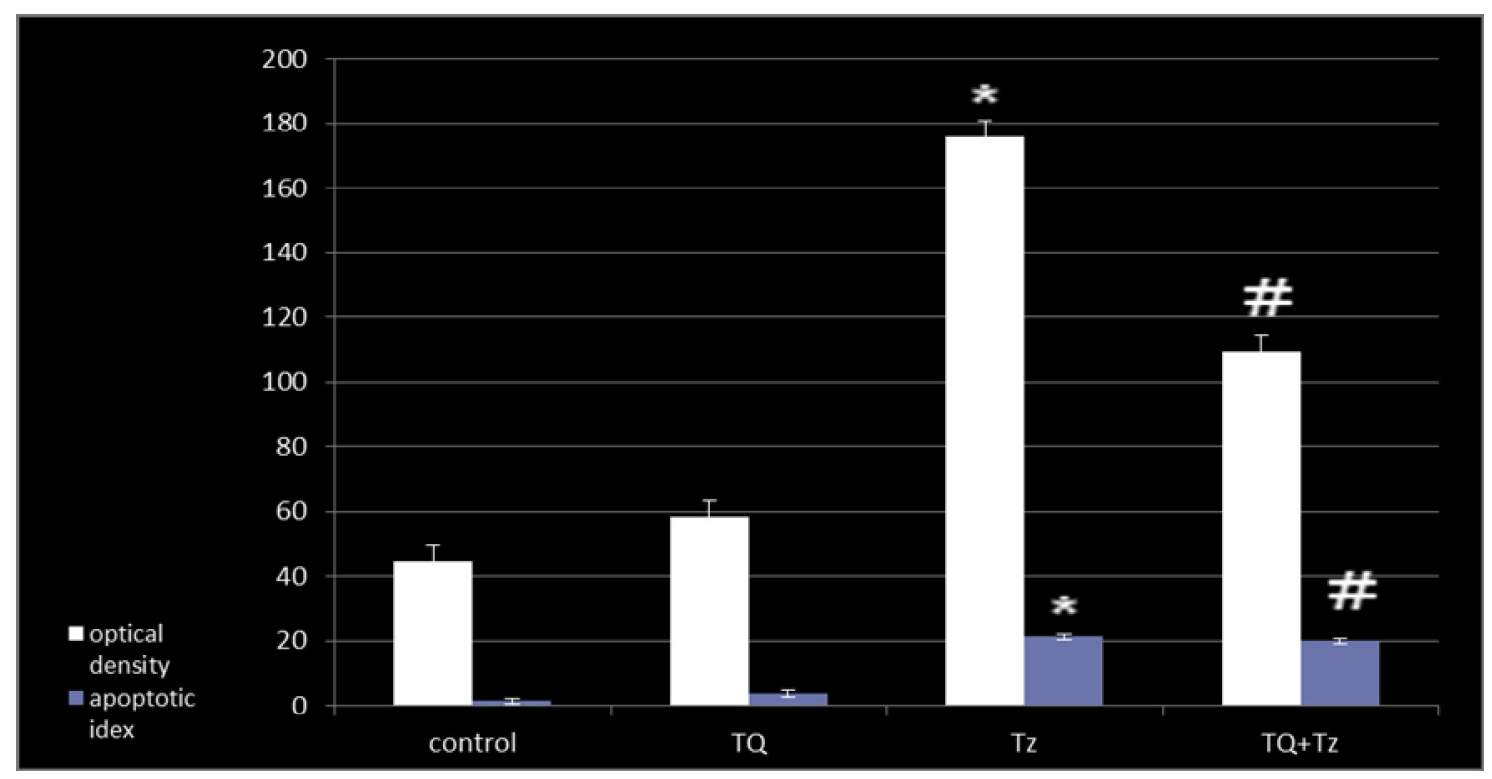

Figure (8): Comparison between the control and treated groups as regard optical density and apoptotic index of the cerebellum. Data represent the means \pm SEM, (*,\#) significant values compared with control, tartrazine; respectively, $\mathrm{P}<0.05$ ), using oneway ANOVA followed by Bonferroni post hoc multiple comparison test. 


\section{DISCUSSION}

The color of food is a feature that makes it attractive and recognizable, especially in modern societies. Many synthetic colors are added to various types of food during its preparation for this reason to enhance such qualities. Children are very fond of colored food. However, it may be the cause of many harmful and toxic effects on the long run.

In the current work, oral administration of $\mathrm{Tz}$ for 30 days evoked marked changes in biochemical analysis of brain homogenate. Regarding the redox state, there was a signi? cant decrease in the activity of CAT and concentration of GSH as well as signi?cant increase in the concentration of MDA, a byproduct of lipid peroxidation, considered as an indication of the severity of the $\mathrm{Tz}$ induced oxidative stress condition. Also, the present study revealed the presence of cerebellar cortex changes in the form of swelling, vacuolar degeneration in all layers mainly in white matter, which induced by oxidative stress of $\mathrm{Tz}$ metabolism. Our results were going hand to hand with data reported by (Mohamed et al., 2015), (Bawazir, 2016) and (Bhatt et al., 2018). Interestingly, the present study revealed that the co-administration of TQ with $\mathrm{Tz}$ ameliorated the toxic effects of $\mathrm{Tz}$ on the brain through an increase in the concentration and activity of GSH and CAT respectively with reduction of MDA level suggesting possible role of TQ in scavenging hydroxyl and peroxyl radicals. Such findings were also in coincidence with the study of (Safhi, 2016) and (Kassab and El-Hennamy, 2017).
Because $\mathrm{Tz}$ is from the group of azo dye food colorants, Azo compounds may reach the intestine directly after oral ingestion or through the bile after parenteral administration. It is subjected to the action of acid, digestive enzymes, and microflora (Amin et al., 2010). Azo dyes were catalyzed by azo reductases and peroxidases, while semiquinone radicals and aromatic amines were the products of these reactions. Some metabolites can be absorbed into the general circulation and may cross the blood-brain barrier (Stevens et al., 2016).

The present study revealed the presence of cerebellar cortex changes in the form of swelling, vacuolar degeneration in all layers mainly in white matter, which induced by oxidative stress of tartrazine metabolism. (Ghonimi and Elbaz, 2015) also proved in their study that the effect of tartrazine on cerebellum mainly observed in the white matter in form of vacuolation, while the gray matter was little affected. The decreased activity of CAT and GSH concentration in brain tissue was due to excess availability of hydrogen peroxide in the biological systems which, in turn, generate hydroxyl and peroxyl radicals, resulting in the initiation and propagation of lipid peroxidation. Brain tissue contains large amounts of polyunsaturated fatty acids, which are predominantly vulnerable to free radical damage and cause vacuolation of cerebellar cortex (Chaudhary et al., 2014).

This study also demonstrated neurodegeneration in Purkinje cells as indicated from the marked necrosis of Purkinje cells, cytoplasmic shrinkage, pyknotic nuclei, and chromatin 
condensation (apoptosis). Similar results proved by (Khadrawy et al., 2017) who attributed these histopathological changes to the excito-toxicity that arises from the excessive stimulation of the N-methyl-Daspartate receptor amino acid receptors (NMDA) by glutamate and aspartate which leads to $\mathrm{Ca} 2+$ overload, oxidative stress and neuroinflammation. Also they found that, the degenerated Purkinje neurons could be attributed to the degeneration of the GABAergic Purkinje cells that control excitability by inhibiting glutamate release.

The present results showed a significant increase in level of proinflammatory cytokine TNF- $\alpha$, proapoptotic $\mathrm{Bcl}-2$ associated $\mathrm{X}$ (Bax) protein versus marked decrease in B-cell lymphoma-2 (Bcl-2) levels of $\mathrm{Tz}$ group indicating cerebellar inflammation and apoptosis. $\mathrm{Tz}$ induced cerebellum neuroinflammation and apoptosis appeared in all layers of the cerebellar cortex mainly white matter and Purkinje cells. These could be a consequence of oxidative stress and alteration of neurotransmitters. The neurochemical consequences of the current study were reinforced by immunohistochemical study of different studied animal groups. Also, (Mohamed et al., 2015) reported numerous apoptotic cells in the brain using an immunohistochemical staining with the anti-ssDNA antibody as apoptotic cell marker as compared to other groups.

Oxidative stress is recognized as a strong mediator of apoptosis. A depletion of reduced glutathione (GSH) has been reported to occur with the onset of apoptosis (EL Kafrawy et al., 2015). TNF$\alpha$, a potent pro-inflammatory cytokine, has a promoting role in neuroinflammationmediated progressive neurodegeneration a consequence of the excitotoxicity and oxidative stress (Khadrawy et al., 2017).

The current study provided clear documents that TQ co-administration reduced the elevated levels of TNF- $\alpha$ and Bax versus marked increase in $\mathrm{Bcl} 2$ in cerebellum of $\mathrm{Tz}$ group which ends up inflammation and the programmed cell death process, in addition to potentially preserved $\mathrm{CB}$ architecture compared to control group. These results were in agreement with data demonstrated by (Ullah et al., 2015) and (Beker et al., 2018) that supported the inflammation/apoptosis-inhibiting effect of TQ. Likewise, TQ decreased TNF- $\alpha$, IL-6 and NO metabolites, and increased thiol content, SOD and CAT in the brain of rats treated with lipopolysaccharides (Bargi et al., 2017).

A variety of mechanisms has proposed to explain the antineuroinflammatory/anti-apoptotic effect of TQ. (Jakaria et al., 2018) suggested that TQ produces anti-neuroin? ammatory activity through the AMP-activated protein kinase (AMPK) and nicotinamide adenine dinucleotide (oxidized)/sirtuin 1 (SIRT1) pathways. Further, TQ diminishes cellular ROS generation, possibly through inhibition of p40phox and gp91phox protein (Velagapudi et al., 2017). Additionally, (Majdalawieh et al., 2015) reported that TQ up-regulates PPAR- $\gamma$, which has an important role in inflammation reduction as well as control over the phosphatidylinositol-3-kinase (PI3K)/Akt balance. Also, (Amin et al., 2016) demonstrated that TQ can inhibit the cyclooxygenase (COX) and 5- 
lipoxygenase (5-LPO) pathways of arachidonate metabolism, respectively.

It has been suggested that Bax, a proapoptotic and $\mathrm{Bcl}-2$, an antiapoptotic member of Bcl-2 family plays a key role in the initiation of intrinsic pathway of apoptosis (Al Mamun et al., 2015). Mitochondria play an important role in apoptosis under a variety of pro-apoptotic conditions, such as oxidative stress and cytochrome-c release. The latter is a key event in the activation of caspase-3, a pivotal downstream step in apoptosis initiation (Ullah et al., 2012). The role of $\mathrm{TQ}$, as free radical scavengers that result from $\mathrm{Tz}$ and its metabolites, could lead to stabilization of the mitochondrial membrane permeability which regulates cytochrome $\mathrm{C}$ release, and other caspaseinduced pro-apopototic factors.

In addition, antiapoptotic effect of TQ could be mediated in part through the suppression of TNF- $\alpha$, and consequently suppression of the NF- $\kappa \mathrm{B}$ activation pathway and targets the apoptotic regulators of the Bcl-2 family proteins. Interestingly, it has been reported that thymoquinone is actually a potent apoptosis inducer in cancer cells, but it exerts antiapoptotic effect through attenuating oxidative stress in other types of cell injury (Abd El-Ghany et al., 2009 and Khan et al., 2017).

TQ treatment reverses the negative effects of $\mathrm{Tz}$ on the brain redox state by the virtue of its antioxidant properties. Strong antioxidant properties of TQ may be related to its structural similarity with the natural mitochondrial electron carrier, ubiquinone. In addition to its unrestricted crossing of morphological barriers, its gains easy access to subcellular compartments and facilitates the ROS scavenging effect by its interaction with the mitochondrial respiratory chain (Staniek and Gille, 2010 and Alenzi et al., 2013). Former studies have concluded that TQ can directly scavenge for superoxide $(\mathrm{O} 2-)$ and hydroxyl radicals $(\mathrm{OH} \bullet)$, suppress mRNA expression of the inducible nitric oxide synthase (iNOS) enzyme, and enhance the expression of antioxidant enzymes' genes, such as CAT and glutathione-Stransferase (Abdel-Daim et al., 2018).

In the present study, the results revealed that oral administration of $\mathrm{Tz}$ to adult male rats for 30 days induced a noticeable decrease in levels of $\mathrm{NE}$ (neurotransmitter affecting eating and sleep), DA (a neurotransmitter that plays a role in learning, attention, and movement), 5HT (neurotransmitter that plays an important role in regulating mood, sleep, aggression, and appetite), and GABA (Main inhibitory neurotransmitter in the brain) of cerebellar homogenate compared to the control groups. Our results were going hand to hand with data reported by (Mohamed et al., 2015) and (Bawazir, 2016) who demonstrated significant decrease of some brain neurotransmitter in rats treated with azo dye. Also, (Gao et al., 2011) reported that $\mathrm{Tz}$ induced neurotoxicity and deficits in learning and memory. The decreases in neurotransmitter in the Tz-treated group may stem from the direct effects of the dye, and/or from the indirect pathway through the reductive biotransformation of the azo bond during metabolism (Chequer et al., 2011-b). These free radicals inhibited formation of adenosine triphosphate that could reduce synthesis or 
re-uptake of neurotransmitter in the presynaptic cell (Bawazir, 2012).

Alteration of brain neurotransmitters has been linked to depression and attention deficit disorder. (Sanacora et al., 2004) reported that perturbation in glutamatergic and GABAergic neurotransmission is associated with several neurological and psychiatric disorders. Cerebellar Purkinje neurons release GABA, which exerts inhibitory actions on the dentate nucleus and certain deep cerebellar output neurons, thereby reducing the transmission of nerve impulses and enabling Purkinje cells to regulate and coordinate motor movements (Bowery et al., 2002). The inhibitory amino acid neurotransmitters can counteract the increase in excitatory neurotransmitters and alleviate its hyperexcitability. Dysfunction of GABAergic neurons such as the imbalanced generation of glutamatergic and GABAergic neurons is implicated as a cause of various neurodevelopmental disorders (Rossignol, 2011).

Thymoquinone co-administration of $\mathrm{Tz}$ group alleviated the changes in monoamine (NE, DA, 5HT) and amino acid (GABA) neurotransmitters of cerebellar homogenate induced by $\mathrm{Tz}$. These results were in agreement with ( $E l$ Naggar et al., 2017) who reported that methanol extraction from Nigella sativa can modify amino acid neurotransmitter level in rat brain region. Also, modulatory effect of TQ on brain neurotransmitters has been reported by (Kassab and ElHennamy, 2017) against metalloid's neurotoxicity. In addition, (Gilhotra and Dhingra, 2011) demonstrated an increase in GABAergic tone in the anxiolytic and anticonvulsant activities of Nigella sativa extracts as well as TQ. (Jakaria et al., 2018) documented that TQ possesses both antidepressant and anxiolytic activities according to mouse models.

\section{CONCLUSION}

Awareness among people should be created about the hazardous effect of $\mathrm{Tz}$ consumption based on the present findings. We proposed that TQ might be a good candidate for protection against artificial food coloring $\mathrm{Tz}$ induced neurotoxicity through its antioxidant, neurotransmitter modifying, antineuroinflammatory and anti-apoptotic effects. In addition, promotion of neurogenesis as well as potential restoration of cerebellar cortex, prevention of neuronal degeneration and apoptosis was also observed.

\section{REFERENCES}

1. Abdel-Daim, M.M.; Shaheen, H.M.; Abushouk, A.I.; Toraih, E.A.; Fawzy, M.S.; Alansari, W.S.; Aleya, L. and Bungau, S. (2018): Thymoquinone and diallyl sulfide protect against fipronil-induced oxidative injury in rats. Environmental Science and Pollution Research, doi: 10.1007/s11356-018-2386-3 [Epub ahead of print].

2. Abd El-Ghany, R.M.; Sharaf, N.M; Kassem, L.A.; Mahran1, L.G. and Heikal, O.L. (2009): Thymoquinone triggers anti-apoptotic signaling targeting death ligand and apoptotic regulators in a model of hepatic ischemia reperfusion injury. Drug Discov Ther., 3(6):296-306.

3. Alenzi1, F.Q.; Altamimi, M.A.A.; Kujan, O.; Tarakji, B.; Tamimi, W.; Bagader, O.; AlShangiti, A.; Talohi, A.N.; Alenezy, A.K.; AlSwailmi, F.; Alenizi, D.; Salem, M.L. and Wyse, R.K.H. (2013): Antioxidant Properties of Nigella sativ. J Mol Genet Med., 7(3):1-5.

4. Al Mamun, A.; Hashimoto, M.; Katakura, M.; Hossain, S. and Shido, O. (2015): 
Neuroprotective effect of thymoquinone against glutamate-induced toxicity in SH-SY5Y cells. Current Topics in Nutraceutical Research, 13 (3): 143-152.

5. Amin, B. and Hosseinzadeh, H. (2016): Black Cumin (Nigella sativa) and its active constituent, thymoquinone: an overview on the analgesic and anti-inflammatory effects. Planta Medica., 82: 8-16.

6. Amin, K.A.; Abdel Hameid, H. and Abd Elsttar, A.H. (2010): Effect of food azo dyes $\mathrm{Tz}$ and carmoisine on biochemical parameters related to renal, hepatic function and oxidative stress biomarkers in young male rats. Food and Chemical Toxicology, 48(10):2994-2999.

7. Amin, K.A. and Al-Shehri, F.S (2018): Toxicological and safety assessment of $\mathrm{Tz}$ as a synthetic food additive on health biomarkers: A review. African Journal of Biotechnology, 17(6): 139-149.

8. Bancroft, J.D. and Gamble, M. (2001): Theory and practice of histological techniques (5thedn.), publisher Edinburgh: Churchill Livingstone, New York.

9. Bargi, R.; Asgharzadeh, F.; Beheshti, F.; Hosseini, M.; Sadeghnia, H.R. and Khazaei, M. (2017): The effects of thymoquinone on hippocampal cytokine level, brain oxidative stress status and memory deficits induced by lipopolysaccharide in rats. Cytokine, 96:17384.

10. Bawazir, A.E. (2012): Effect of chocolate brown HT with olive oil on some neurotransmitters in different brain regions, physiological and histological structure of liver and kidney of male albino rats. $\mathbf{J}$ of Evolutionary Bio Res., 4(1):13- 23.

11. Bawazir, A.E. (2016): Effects of Food Colour Allura Red (No. 129) on some neurotransmitter, Antioxidant Functions and Bioelement Contents of Kidney and Brain Tissues in male albino Rats. Life Science J., 13 (12):10-17.

12. Beker, M.; Dall, T. and Elibol, B. (2018): Thymoquinone Can Improve Neuronal Survival and Promote Neurogenesis in Rat Hippocampal Neurons. Mol Nutr Food Res., 62: 1-10.

13. Bhatt, D.; Vyas, K.; Singh, S.; John, P.J. and Soni, I (2018): $\mathrm{Tz}$ induced neurobiochemical alterations in rat brain subregions. Food and Chemical Toxicology, 113: 322-327.

14. Bowery, N.G.; Bettler, B.; Froestl, W.; Gallagher, J.P.; Marshall, F.; Raiteri, M.; Bonner, T.I. and Enna, S.J. (2002): International union of pharmacology. XXXIII. Mammalian gamma-aminobutyric acid (B) receptors: Structure and function. Pharmacol Rev., 54: 247-264.

15. Chaudhary, M.; Joshi, D.K.; Tripathi, S.; Kulshrestha, S. and Mahdi, A.A. (2014): Docosahexaenoic acid ameliorates aluminum induced biochemical and morphological alteration in rat cerebellum. Ann Neurosci., 21(1):5-9.

16. Chequer, F.M.D.; Dorta, D.J. and de Oliveira, D.P. (2011-a): Chequer, F.M.D.; Dorta, D.J. and de Oliveira, D.P. (2011-a): Azo dyes and their metabolites: does the discharge of the azo dye into water bodies represent human and ecological risks? In: Hauser PJ, editor. Advances in Treating Textile Ef?uent: $27-48$.

17. Chequer, F.M.D.; Lizier, T.M.; de Felicio, R.; Zanoni, M.V.B.; Debonsi, H.M.; Lopes, N.P.; Marcos, R. and de Oliveira, D.P. (2011b): Analyses of the genotoxic and mutagenic potential of the products formed after the biotransformation of the azo dye. Disperse Red Toxicol in vtro, 25:2054-2063.

18. EL Kafrawy, M.H.; Yousuf, A.F.; Abd Elwahab, A.H. and El Anan, M.G. (2015): The protective effect of allium cepa (onion) extract against potential hepatotoxic effect of aspartame in male rats. Egypt J Med Sci., 36 (2):840-865.

19. Ellman, G.L. (1959): Tissue sulfhydryl groups. Arch Biochem Biophys.,82: 70-77.

20. Elmaci, I. and Altinoz, M.A. (2016): Thymoquinone; an edible redox-active quinone for the pharmacotherapy of neurodegenerative conditions and glial brain tumors. Biomed Pharmacother., 83:635-40.

21. El-Naggar, T.; Carreteroa, M.E.; Arcec, C. and Gomez-Serranillosa, M.P. (2017): Methanol extract of Nigella sativa seed induces changes in the levels of neurotransmitter amino 


\section{EMAN S. MAHMOUD et al.}

acids in male rat brain regions. Pharmaceutical Biology, 55(1):1415-1422.

22. Gao, Y.; Li, C.; Shen, J.; Yin, H.; An, X. and Jin, H. (2011): Effect of Food Azo Dye Tz on Learning and Memory Functions in Mice and Rats, and the Possible Mechanisms Involved. J Food Sci, 76 (6): 125-130.

23. Ghonimi, W.A.M. and Elbaz, A. (2015): Histological changes of selected Wistar rat tissues following the ingestion of tartrazine with special emphasis on the protective effect of royal jelly and cod liver oil. J Cytol Histol., 6 (4): 1000346.

24. Gilhotra, N. and Dhingra, D. (2011): Thymoquinone produced antianxiety-like effects in mice through modulation of GABA and NO levels. Pharmacol Rep., 63: 660-669.

25. Guo, H.; Hu, L.M.; Wang, S.X.; Wang, Y.L.; Shi, F.; Li, H.; Liu, Y.; Kang, L.Y. and Gao, X.M. (2011): Neuroprotective effects of scutellarin against hypoxic-ischemic-induced cerebral injury via augmentation of antioxidant defense capacity. Chin J Physiol., 54(6): 399405.

26. Jakaria, M.D.; Cho, D-Y.; Haque, M.E.; Karthivashan, G.; Kim, I-S.; Ganesan, P.; and Choi, D-K. (2018): Neuropharmacological potential and delivery prospects of thymoquinone for neurological disorders. Oxidative Medicine and Cellular Longevity, Article ID 1209801, 17 pages.

27. Kassab, R.B. and El-Hennamy, R.E. (2017): The role of thymoquinone as a potent antioxidant in ameliorating the neurotoxic effect of sodium arsenate in female rat. Egyptian J of Basic and Applied Sciences, 4: 160-167.

28. Khadrawy, Y.A.; Mourad, I.M.; Mohammed, H.S.; Noor, N.A. and Aboul Ezz, H.S. (2017): Cerebellar neurochemical and histopathological changes in rat model of Parkinson's disease induced by intrastriatal injection of rotenone. Gen Physiol Biophys., 36: 99-108.

29. Khan, M.A.; Tania, M.; Fu, S. and Fu, J. (2017): Thymoquinone, as an anticancer molecule: from basic research to clinical investigation. Oncotarget, 8 (31): 51907-51919.
30. Majdalawieh, A.F. and Fayyad, M.W. (2015): Immunomodulatory and antiinflammatory action of Nigella sativa and thymoquinone: A comprehensive review. International Immunopharmacology, 28: 295304.

31. Mohamed, A.A.; Galal, A.A. and Elewa, Y.H. (2015): Comparative protective effects of royal jelly and cod liver oil against neurotoxic impact of $\mathrm{Tz}$ on male rat pups brain. Acta Histochem., 117(7):649-58.

32. Ohkawa, H.; Ohishi, N. and Yagi, K. (1979): Assay for lipid peroxides in animal tissues by thiobarbituric acid reaction. Anal Biochem., 95:351-358.

33. Pagel, P.; Blome, J. and Wolf, H.U. (2000): High-performance liquid chromatographic separation and measurement of various biogenic compounds possibly involved in the pathomechanism of Parkinson's disease. J Chromatogr B., 746 (2):297-304.

34. Pamidi, N.; Nayak, B.S.; Mohandas, K.G.; Rao, S.S. and Madhav, N.V. (2014): Environmental enrichment exposure restrains the neuronal damage induced by diabetes and stress in the motor cortex of rat brain. BratislLekListy, 115 (4):197-202.

35. Rossignol, E. (2011): Genetics and function of neocortical GABAergic interneurons in neurodevelopmental disorders. Neural Plast., 649325 .

36. Safhi, M.M. (2016): Neuromodulatory effects of thymoquinone in extenuating oxidative stress in chlorpromazine treated rats. Acta Poloniae Pharmaceutical Drug Research, 73 (2): 529535.

37. Sanacora, G.; Gueorguieva, R.; Epperson, C.N.; Wu, Y.T.; Appel, M.; Rothman, D.L.; Krystal, J.H. and Mason, G.F.(2004): Subtype- specific alterations of gammaaminobutyric acid and glutamate in patients with major depression. Arch Gen Psychiatry, 61: 705-713.

38. Şekeroglu, Z.A.; Guneş, B.; Yedier, S.K.; Şekeroglu, V. and Aydın, B. (2017): Effects of $\mathrm{Tz}$ on proliferation and genetic damage in human lymphocytes. Toxicology Mechanisms and Methods, 27(5):370-375. 
39. Staniek, K. and Gille, L. (2010): Is thymoquinone an antioxidant? BMC Pharmacology, 10(1): A9.

40. Stevens， L.J.; Kuczek，T.; Burgess，J.R.; Stochelski, M.A.; Arnold, L.E. and Galland, L. (2016): Mechanisms of behavioral, atopic, and other reactions to arti? cial food colors in children. Nutrition reviews, Oxford J, 71 (5):268-281.

41. Ullah, I.; Badshah, H.; Naseer, M.I.; Lee, H.Y. and Kim, M.O. (2015): Thymoquinone and vitamin $\mathrm{C}$ attenuates pentylenetetrazoleinduced seizures via activation of GABAB1 receptor in adult rats cortex and hippocampus. Neuromol Med., 17(1):35-46.

42. Ullah, I.; Ullah, N.; Naseer, M.I.; Lee, H.Y. and Kim, M.O. (2012): Neuroprotection with metformin and thymoquinone against ethanolinduced apoptotic neurodegeneration in prenatal rat cortical neurons. BMC Neuroscience, https://doi.org/10.1186/14712202-13-11.
43. Velagapudi, R.; El-Bakoush, A.; Lepiarz, I.; Ogunrinade, F. and Olajide, O.A. (2017): AMPK and SIRT1 activation contribute to inhibition of neuroin?ammation by thymoquinone in BV2 microglia. Molecular and Cellular Biochemistry, 435 (1-2): 149-162.

44. Xu, C.; Shu, W.Q.; Qiu, Z.Q.; Chen, J.A.; Zhao, Q. and Cao, J. (2007): Protective effects of green tea polyphenols against subacute hepatotoxicity induced by microcystin-LR in mice. Environ Toxicol Pharาmacol., 24: 140-148.

45. Zarnescu, O.; Brehar, F.M.; Chivu, M. and Ciurea, A.V. (2008): Immunohistochemical localization of cas-pase-3, caspase-9 and Bax in U87 glioblasto $\neg$ maxenografts. J Mol Histol., 39: 561-569. 


\section{التأثير التخفيفى للثيموكينون على الاصسابات المخيخية المسببة بصبغة الآزو الغذائية فى الجرذان الانيان \\ ايمان سعيد محمود ـ عزة حامد عبد الوهاب* ـ أسماء فتحى يوسف \\ قسم الهستولوجى- قسم الفيسيولوجى* ـ كلية الطب - جامعة الأزهر}

خلفية البحث : يعد البحث عن الأطعمة المغذية أحد أهم وظائف الدماغ ،يعتمد هذا النشـاط في المقام

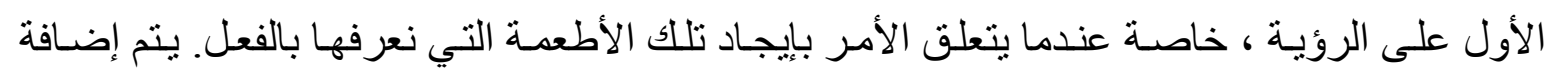

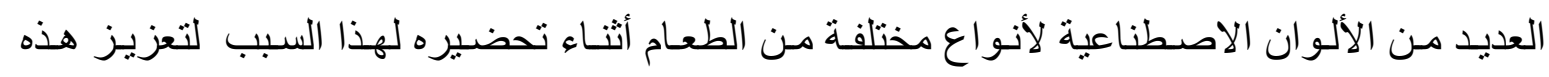

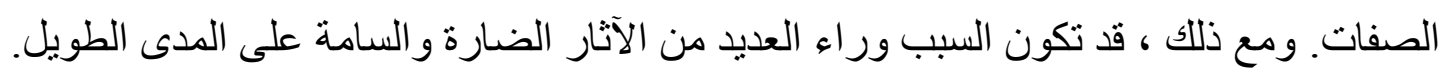

الهـف من البحث: تقييم الدور التحسيني المحتمل للثيموكينون ضد التأثير السـام العصبي المحتمل للترتر ازين وهو صبغة آزو اصطناعية تستخدم على نطاق واسع.

مواد والأساليب: تم تخصيص أربعين من ذكور الجرذان البالغين إلى أربع مجمو عات. تلقت المجموعة

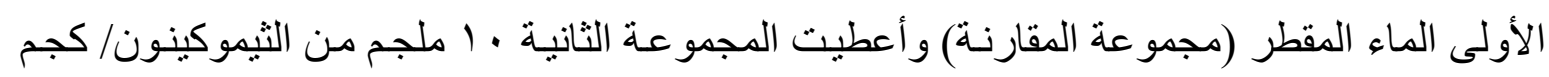

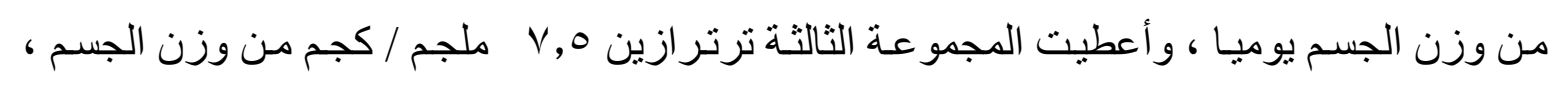

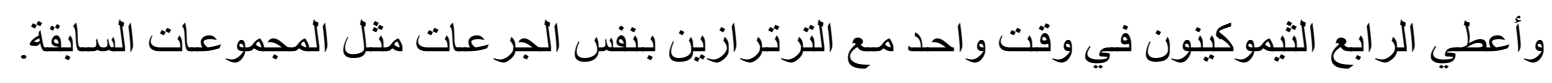

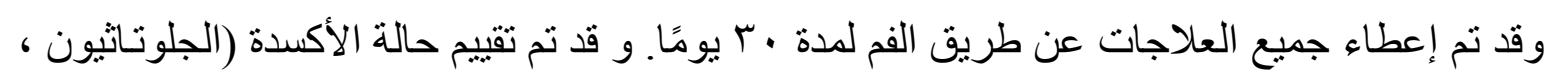

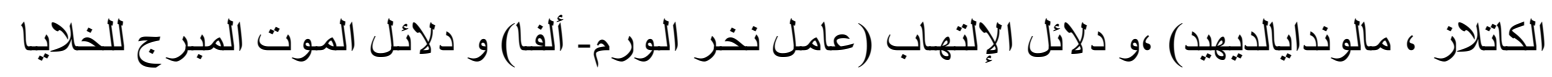

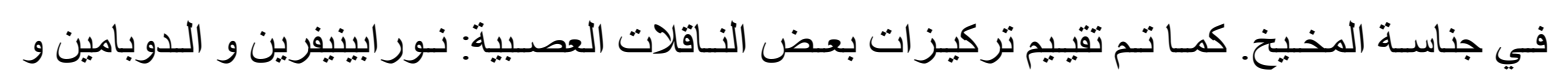

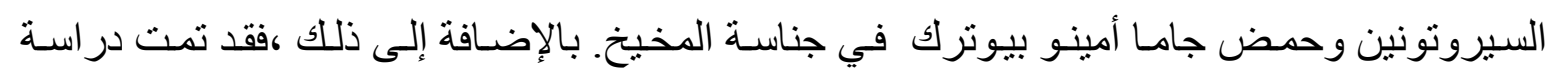
هنتوباثولوجيا من القترة المخيخية.

النتائج: تسبب الترتر ازين فى انخفاض فى الناقلات العصبية المقاسـة"النور ابينيفرين-الدوبامين -

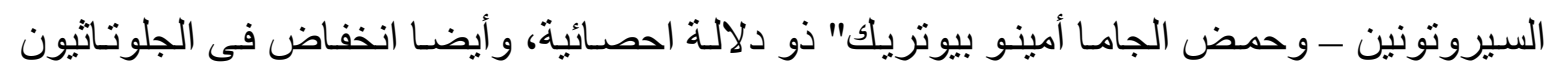

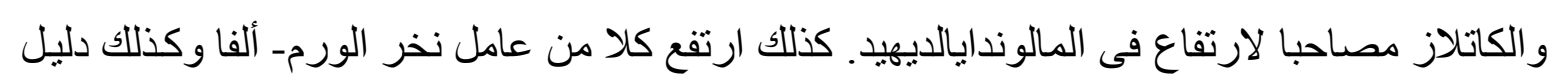

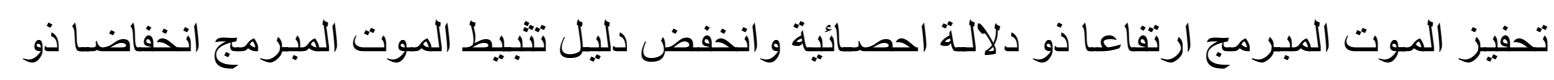

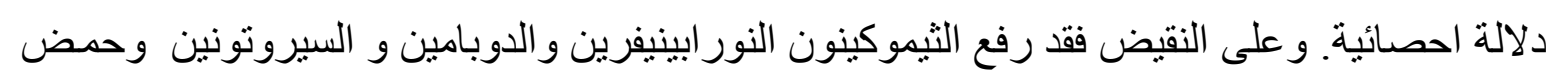

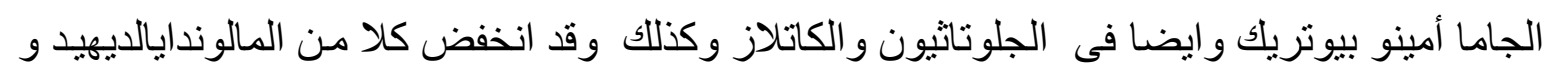

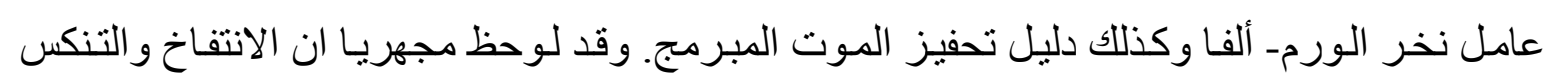


الفجوي في طبقات قشترة المخيخ مـع قلـة خلايـا بركينجي وزيـادة معامل موت الخلايـا المبرمج التى تسبب بها الترتر ازين قد تحسن بتتاول الثيموكينون مـع التتر ازين و استعادت معظم خلايـا برجينجي صورتها النمطيةكما في المجمو عة الضابطة.

الاستنتاج: قد يكون الثيموكينون مرشـحًا جيدًا لتحسين السمية العصبية الناتجة عن الترتر ازين من خـلال تـأثيره على مضـادات الأكسـدة ، وتعديل النـاقلات العصـبية ، و التـأثنير ات المضــادة للالتهـاب العصبي و التأثير ات المضادة لموت الخلايا المبرمج. 